\title{
Yield potential and economics of rabi sorghum (Sorghum bicolor L.) as influenced by different crop residues and green biomass composts
}

\author{
Ashwini Ambadi ${ }^{1}$, D. Krishnamurty ${ }^{2 *}$, Sathyanaran Rao ${ }^{3}$, B.K. Desai ${ }^{1}$, M.V. Ravi ${ }^{4}$ and \\ S. Shubha ${ }^{5}$ \\ ${ }^{1}$ Department of Agronomy, University of Agricultural Sciences, Raichur-584104 (Karnataka), INDIA \\ ${ }^{2}$ Directorate of Research, University of Agricultural Sciences, Raichur-584 104 (Karnataka), INDIA \\ ${ }^{3}$ Research Institute on Organic Farming, University of Agricultural Sciences, Raichur-584 104 (Karnataka), INDIA \\ ${ }^{4}$ Department of Soil Science, University of Agricultural Sciences, Raichur-584 104 (Karnataka), INDIA \\ ${ }^{5}$ Department of Agricultural Microbiology, University of Agricultural Sciences,Raichur-584104(Karnataka),INDIA \\ *Corresponding author. E-mail: murthyagron@gmail.com
}

Received: December 10, 2016; Revised received: August 20, 2017; Accepted: January 17, 2018

\begin{abstract}
A field experiment was conducted on vertisols at Organic Farming Research Institute, University of Agricultural Sciences, Raichur coming under northern Karnataka during rabi season of 2015-16 to study the yield potential ( $\mathrm{q} \mathrm{ha}^{-1}$ ) and economics of rabi sorghum (Sorghum bicolor L.) as influenced by different crop residues and green biomass composts. The experiment consisted of fifteen treatments, of which twelve treatments were based on nitrogen supply though different composts, one recommended dose of fertilizer, one recommended organic and inorganic fertilizers and another was absolute control. Significantly higher grain yield (39.9 $\left.\mathrm{q} \mathrm{ha} \mathrm{h}^{-1}\right)$ and stover yield (13.2 tha$\left.{ }^{1}\right)$ was recorded with application of FYM @ $3 \mathrm{t} \mathrm{ha}^{-1}+\mathrm{RDF}\left(50: 25 \mathrm{~N}: \mathrm{P}_{2} \mathrm{O}_{5} \mathrm{~kg} \mathrm{ha}^{-1}\right)$ followed by recommended NP fertilizers ( $\left.\mathrm{T}_{13}: 37.2 \mathrm{q} \mathrm{ha}^{-1}\right)$ and Cotton stalks +Redgram stalks + Glyricidiasp. with $\mathrm{C}: \mathrm{N}$ ratio of 30:1 compost @ $50 \mathrm{~kg} \mathrm{~N}$ equivalent $\left(T_{12}: 36.6 \mathrm{q} \mathrm{ha}^{-1}\right)$. The lowest grain yield was recorded with absolute control $\left(\mathrm{T}_{15}: 18.4 \mathrm{q} \mathrm{ha}^{-1}\right)$. Significantly higher $\mathrm{B}: \mathrm{C}(3.08)$ was recorded with $\mathrm{RDF}\left(50: 25 \mathrm{~N}: \mathrm{P}_{2} \mathrm{O}_{5} \mathrm{~kg} \mathrm{ha}^{-1}\right)+\mathrm{FYM} @ 3 \mathrm{t} \mathrm{ha} \mathrm{h}^{-1}$ application followed Cotton stalks +Redgram stalks + Glyricidia sp. with C: N ratio of 30:1 compost @ 50 kg N equivalent $\left(T_{12}: 2.90\right)$ over other treatments. Application of recommended FYM @ $3 \mathrm{t} \mathrm{ha}^{-1} 15$ days before sowing along with $50 \mathrm{~kg}$ of nitrogen and 25 $\mathrm{kg}$ of phosphorus per hectare at the time of sowing recorded higher dry matter production, grain and stover yield and net returns and benefit: cost ratio.
\end{abstract}

Keywords: Cotton stalks, Compost, RDF, Red stalks, Sorghum

\section{INTRODUCTION}

Sorghum (Sorghumbicolor L.) is a fifth most important cereal crop in the world after wheat, maize, rice and barley (Taylor, 2003). Sorghum in India is cultivated during both rainy (kharif) and post-rainy ( $r a b i)$ season, mainly as a rainfed crop. Maharashtra is the largest sorghum grower and producer followed by Karnataka, Madhya Pradesh and Andhra Pradesh. Sorghum is grown in $6.16 \mathrm{~m}$. ha with a productivity of $5.45 \mathrm{~m} \mathrm{t}$ and yield of $884 \mathrm{~kg} \mathrm{ha}^{-1}$ in the country (Anonymous, 2014). Sorghum cultivation is gaining popularity due to its nature of extreme drought tolerance and is very nutritious just like corn and can be used as green fodder, dry fodder, hay or silage. The agricultural wastes include leaves, straw, husk left in the field after harvest, hulls and shells removed during processing of crops at the mills as well as animal dung. Cotton (7.57 lha) and redgram (6.831ha) are major crops grown in northern Karnataka region during 2014-15 (Anonymous, 2015) and stalks of these crops are burnt after harvest causes environmental pollution. All these crop residues viz. crop by-products have low fodder value or waste of threshing yard, which have high carbon to nitrogen ratio (22 to 99:1) and less suitable for direct use. Further the quality of the conventional organic manure is poor. In addition to this some of the farmers are using these stalks as source of raw materials for production of composts without knowing exact proportion of mixing green biomass and its impact on crops and soil. Therefore, to develop a suitable technique for production of enriched organic manure with crop residues and green biomass, as a nutrient source and enrichment is best remedy for maintaining soil quality as well as productivity of rabi sorghum. Keeping these points in view, the present investigation was carried out to study the efficacy of enriched composts on growth, productivity and economics of rabi sorghum.

\section{MATERIALS AND METHODS}

A field experiment was conducted during rabiseason 
of 2015-16 at Organic Farming Research Institute, University of Agricultural Sciences, Raichursituated in North Eastern Dry Zone of Karnataka at $16^{\circ} 15^{\prime} \mathrm{N}$ latitude and $77^{\circ} 20^{\prime} \mathrm{E}$ longitude with an altitude of 389 meters above the mean sea level. A composite soil sample was collected from 0 to $15 \mathrm{~cm}$ depth in experimental plot before sowing. Soil sample was air dried, powdered, passed through $2 \mathrm{~mm}$ sieve and analysed for physic-chemical and biological properties of soil. The soil was deep black clayey in texture with $\mathrm{pH}$ of 7.56 with organic carbon content of $0.55 \%$. The soils were low in available nitrogen $\left(140.28 \mathrm{~kg} \mathrm{ha}^{-1}\right)$ and high in available phosphorus $\left(55.34 \mathrm{~kg} \mathrm{ha}^{-1}\right)$ and high in available potassium (413.21 $\left.\mathrm{kg} \mathrm{ha}^{-1}\right)$. The experiment consisted of fifteen treatments, of which twelve treatments were based on recommended nitrogen supply through different composts with recommended FYM $\left(3 \mathrm{t} \mathrm{ha}^{-1}\right)+$ fertilizers RDF $\left(50: 25 \mathrm{~N}: \mathrm{P}_{2} \mathrm{O}_{5} \mathrm{~kg}\right.$ ha $\left.{ }^{1}\right)$, $\mathrm{RDF}\left(50: 25 \mathrm{~N}: \mathrm{P}_{2} \mathrm{O}_{5} \mathrm{~kg} \mathrm{ha}^{-1}\right)$ and one absolute control (Table 1).

The experiment was laid in RCBD (Randomized Complete Block Design) with three replications. Sorghum (M 35-1) was sown in the first fort night of October in $45 \mathrm{~cm} \times 15 \mathrm{~cm}$ spacing and each treatment has a gross plot size of $4.5 \mathrm{~m} \mathrm{X} 3.0 \mathrm{~m}$. The required quantity of twelve types of composts and FYM was applied in to soil 15 days before sowing and entire dose of nitrogen and phosphorous fertilizers applied on the day of sowing and incorporated in to soil as per the university recommendation. Nutrient sources used were urea and diammonium phosphate, respectively. Recommended packages of practices were adopted for crop production. The cost of inputs, labour charges and prevailing market rates of farm produce were taken into consideration for working out cost of cultivation, gross returns and net returns per hectare. The analysis and interpretation of data were done using the Fisher's method of analysis and variance technique as given by Panse and Sukhatme (1967). The level of significance used in " $F$ " and " $t$ " test was at $5 \%$ probability level and wherever " $F$ " test was found significant, the " $t$ " test was per- formed to estimate critical differences among various treatments.

\section{RESULTS AND DISCUSSION}

Dry matter production: The dry matter accumulation $\left(\mathrm{g}\right.$ plant $\left.{ }^{-1}\right)$ is the resultant of various growth attributing characters. In the present study, application of recommended FYM (3 $\left.\mathrm{t} \mathrm{ha}^{-1}\right)$ and NP fertilizers applied through DAP and urea (50:25 $\left.\mathrm{kg} \mathrm{N}, \mathrm{P}_{2} \mathrm{O}_{5} \mathrm{ha}^{-1}\right)$ recorded significantly higher dry matter accumulation per plant at 90 DAS and at harvest $\left(\mathrm{T}_{14}: 162.1\right.$ and $203.9 \mathrm{~g}$ plant $^{-1}$, respectively) over other treatments and was on par with recommended NP fertilizers $\left(\mathrm{T}_{13}: 154.2\right.$ and $196.1)$ or $\mathrm{C}_{12}$ compost @ $50 \mathrm{~kg} \mathrm{~N}$ equivalent $\left(\mathrm{T}_{12}\right.$ : 151.1 and 192.4). Absolute control recorded significantly lower dry matter accumulation per plant $\left(T_{15}\right.$ : 90.4 and 131.6 g plant $^{-1}$, respectively). This might be attributed to initial vigorous growth of sorghum might be responsible for intercepting the sunlight to encourages the crop growth and indirectly boosted the plants to record higher plant height and growth attributes (Table 2). The source of nitrogen from FYM/Composts resulted in taller plants because nitrogen was found to increase number of nodes as well as inter node length and consequently plant height. This is attributed to luxuriant growth, increased plant height $(275.3 \mathrm{~cm})$, number of green leaves (7.8) and leaf area $\left(15.5 \mathrm{dm}^{2}\right.$ plant $^{-1}$ ) of plants utilized the resource efficiently resulting in higher dry matter accumulation (203.9 $\mathrm{g} \mathrm{plant}^{-1}$ ). These results are conformity with findings of Feisal et al. (2012) who reported that chicken manure resulted in an increase in growth attributes (plant height, stem diameter and number of leaves) as well as forage yield of sorghum. Chicken manure (5.0 ton/ha) produced higher fresh and dry forage at harvest than the control.

Yield and yield attributes: The grain $\left(\mathrm{q} \mathrm{ha}{ }^{-1}\right)$ and stover yield $\left(\mathrm{t} \mathrm{ha}^{-1}\right)$ of rabi sorghum were significantly $(\mathrm{P}=0.05)$ influenced by the application of different crop residues and green biomass composts and inorganic fertilizers (Table 3). Significantly higher grain and stover yield was obtained with application of RDF

Table 1. Compost and treatment details.

\begin{tabular}{|c|c|c|}
\hline Compost & Treatment No & Treatment details \\
\hline $\mathrm{C}_{1}$ & $\mathrm{~T}_{1}$ & Cotton stalks with the initial $\mathrm{C}: \mathrm{N}$ of $96: 1$ \\
\hline $\mathrm{C}_{2}$ & $\mathrm{~T}_{2}$ & Redgram stalks with the initial C: $\mathrm{N}$ of $80: 1$ \\
\hline $\mathrm{C}_{3}$ & $\mathrm{~T}_{3}$ & Glyricidia $s p$. with the initial C:N of $22: 1$ \\
\hline $\mathrm{C}_{4}$ & $\mathrm{~T}_{4}$ & Cotton stalks + Glyricidia $s p$. with initial $\mathrm{C}: \mathrm{N}$ of $50: 1$ \\
\hline $\mathrm{C}_{5}$ & $\mathrm{~T}_{5}$ & Cotton stalks + Glyricidia $s p$. with initial C: $\mathrm{N}$ of $40: 1$ \\
\hline $\mathrm{C}_{6}$ & $\mathrm{~T}_{6}$ & Cotton stalks + Glyricidia $s p$. with initial C:N of $30: 1$ \\
\hline $\mathrm{C}_{7}$ & $\mathrm{~T}_{7}$ & Redgram stalks + Glyricidia $s p$. with initial C:N of $50: 1$ \\
\hline $\mathrm{C}_{8}$ & $\mathrm{~T}_{8}$ & Redgram stalks + Glyricidia $s p$. with initial C:N of $40: 1$ \\
\hline $\mathrm{C}_{9}$ & $\mathrm{~T}_{9}$ & Redgram stalks + Glyricidia $s p$. with initial C:N of $30: 1$ \\
\hline $\mathrm{C}_{10}$ & $\mathrm{~T}_{10}$ & Cotton stalks + Redgram stalks + Glyricidia sp. with initial C:N of 50:1 \\
\hline $\mathrm{C}_{11}$ : & $\mathrm{T}_{11}$ : & Cotton stalks + Redgram stalks + Glyricidia sp. with initial C:N of $40: 1$ \\
\hline $\mathrm{C}_{12}$ & $\mathrm{~T}_{12}$ & Cotton stalks + Redgram stalks + Glyricidia $s p$. with initial C:N of $30: 1$ \\
\hline- & $\mathrm{T}_{13}$ & Recommended NP fertilizers $\left(50: 25 \mathrm{~N}, \mathrm{P}_{2} \mathrm{O}_{5} \mathrm{~kg} \mathrm{ha}^{-1}\right)$ \\
\hline- & $\mathrm{T}_{14}$ & Recommended FYM (3 $\left.\mathrm{tha}^{-1}\right)$ and NP fertilizers $\left(50: 25 \mathrm{~N}, \mathrm{P}_{2} \mathrm{O}_{5} \mathrm{~kg} \mathrm{ha}^{-1}\right)$ \\
\hline- & $\mathrm{T}_{15}$ & Absolute control \\
\hline
\end{tabular}


Table 2. Total Dry matter production $\left(\mathrm{g} \mathrm{plant}^{-1}\right)$ and length of earhead $(\mathrm{cm})$ in rabi sorghum at different growth stages as influenced by different composts

\begin{tabular}{|c|c|c|c|}
\hline \multirow{2}{*}{ Treatments } & \multicolumn{2}{|c|}{ Dry matter production } & \multirow{2}{*}{$\begin{array}{l}\text { Length of ear } \\
\text { head }(\mathrm{cm})\end{array}$} \\
\hline & 90 DAS & At harvest & \\
\hline $\mathrm{T}_{1}: \mathrm{C}_{1}$-Compost & 127.3 & 169.0 & 18.5 \\
\hline $\mathrm{T}_{2}: \mathrm{C}_{2}$-Compost & 131.8 & 175.0 & 19.4 \\
\hline $\mathrm{T}_{3}: \mathrm{C}_{3}$-Compost & 137.3 & 179.4 & 20.3 \\
\hline $\mathrm{T}_{4}: \mathrm{C}_{4}$-Compost & 128.1 & 169.7 & 18.2 \\
\hline $\mathrm{T}_{5}: \mathrm{C}_{5}$-Compost & 130.0 & 171.4 & 18.9 \\
\hline $\mathrm{T}_{6}: \mathrm{C}_{6}$-Compost & 131.4 & 172.8 & 19.3 \\
\hline $\mathrm{T}_{7}: \mathrm{C}_{7}$-Compost & 133.0 & 173.9 & 16.4 \\
\hline $\mathrm{T}_{8}: \mathrm{C}_{8}$-Compost & 135.5 & 176.4 & 17.6 \\
\hline $\mathrm{T}_{9}: \mathrm{C}_{9}$-Compost & 137.3 & 178.1 & 20.0 \\
\hline $\mathrm{T}_{10}: \mathrm{C}_{10}$-Compost & 144.9 & 185.4 & 17.3 \\
\hline $\mathrm{T}_{11}: \mathrm{C}_{11}$-Compost & 146.9 & 186.9 & 17.8 \\
\hline $\mathrm{T}_{12}: \mathrm{C}_{12}$-Compost & 151.1 & 192.4 & 21.2 \\
\hline $\mathrm{T}_{13}$ : Recommended NP fertilizers $\left(50: 25 \mathrm{~kg} \mathrm{~N}, \mathrm{P}_{2} \mathrm{O}_{5} \mathrm{ha}^{-1}\right)$ & 154.2 & 196.1 & 20.0 \\
\hline $\begin{array}{l}\mathrm{T}_{14} \text { : Recommended FYM }\left(3 \mathrm{t} \mathrm{ha}^{-1}\right) \text { and NP fertilizers }(50: 25 \mathrm{~kg} \mathrm{~N} \text {, } \\
\left.\mathrm{P}_{2} \mathrm{O}_{5} \mathrm{ha}^{-1}\right)\end{array}$ & 162.1 & 203.9 & 21.5 \\
\hline $\mathrm{T}_{15}$ : Absolute control & 90.4 & 131.6 & 15.4 \\
\hline S.Em \pm & 4.10 & 4.85 & 0.29 \\
\hline C.D. $(P=0.05)$ & 12.15 & 14.5 & 0.85 \\
\hline
\end{tabular}

$\mathrm{T}_{1}$ to $\mathrm{T}_{12}$ :Compost was applied @ $50 \mathrm{~kg} \mathrm{~N} \mathrm{ha}^{-1}$

Table 3. Yield attributes, grain yield and stover yield of rabi sorghum as influenced by different crop residues and green biomass composts

\begin{tabular}{|c|c|c|c|c|}
\hline Treatments & $\begin{array}{l}\text { Number of } \\
\text { grains } \\
\text { earhead }^{-1}\end{array}$ & $\begin{array}{l}\text { Test weight } \\
\left(\text { g } 1000 \text { grains }^{-1}\right)\end{array}$ & $\begin{array}{l}\text { Grain } \\
\text { yield } \\
\left(\mathrm{q} \text { ha }^{-1}\right)\end{array}$ & $\begin{array}{l}\text { Stover } \\
\text { yield } \\
\left(\mathrm{t} \mathrm{ha} \mathbf{h}^{-1}\right)\end{array}$ \\
\hline $\mathrm{T}_{1}: \mathrm{C}_{1}$-Compost & 2245.7 & 28.2 & 29.7 & 11.5 \\
\hline $\mathrm{T}_{2}: \mathrm{C}_{2}$-Compost & 2584.8 & 30.5 & 30.7 & 11.8 \\
\hline $\mathrm{T}_{3}: \mathrm{C}_{3}$-Compost & 2685.3 & 31.6 & 32.0 & 12.0 \\
\hline $\mathrm{T}_{4}: \mathrm{C}_{4}$-Compost & 2185.6 & 29.2 & 31.0 & 11.7 \\
\hline $\mathrm{T}_{5}: \mathrm{C}_{5}$-Compost & 2268.2 & 30.1 & 31.3 & 11.8 \\
\hline $\mathrm{T}_{6}: \mathrm{C}_{6}$-Compost & 2489.5 & 31.6 & 31.3 & 11.7 \\
\hline $\mathrm{T}_{7}: \mathrm{C}_{7}$-Compost & 2492.4 & 31.4 & 31.5 & 12.2 \\
\hline $\mathrm{T}_{8}: \mathrm{C}_{8}$-Compost & 2645.3 & 31.6 & 32.5 & 12.4 \\
\hline $\mathrm{T}_{9}: \mathrm{C}_{9}$-Compost & 2864.0 & 31.9 & 32.8 & 12.2 \\
\hline $\mathrm{T}_{10}: \mathrm{C}_{10}$-Compost & 2901.5 & 32.2 & 34.0 & 12.6 \\
\hline $\mathrm{T}_{11}: \mathrm{C}_{11}$-Compost & 2925.8 & 31.6 & 34.3 & 12.7 \\
\hline $\mathrm{T}_{12}: \mathrm{C}_{12}$-Compost & 3014.2 & 33.2 & 36.6 & 12.9 \\
\hline $\mathrm{T}_{13}:$ Recommended NP fertilizers $\left(50: 25 \mathrm{~kg} \mathrm{~N}, \mathrm{P}_{2} \mathrm{O}_{5} \mathrm{ha}^{-1}\right)$ & 3128.2 & 33.0 & 34.2 & 12.2 \\
\hline $\begin{array}{l}\mathrm{T}_{14} \text { : Recommended FYM }\left(3 \mathrm{t} \mathrm{ha}^{-1}\right) \text { and NP fertilizers } \\
\left(50: 25 \mathrm{~kg} \mathrm{~N}, \mathrm{P}_{2} \mathrm{O}_{5} \mathrm{ha}^{-1}\right)\end{array}$ & 3204.6 & 34.4 & 39.7 & 13.2 \\
\hline $\mathrm{T}_{15}$ : Absolute control & 1685.6 & 23.6 & 18.4 & 9.5 \\
\hline S.Em \pm & 84.8 & 0.41 & 1.47 & 0.12 \\
\hline C.D. $(P=0.05)$ & 254.5 & 1.22 & 4.25 & $\mathbf{0 . 3 2}$ \\
\hline
\end{tabular}

$\mathrm{T}_{1}$ to $\mathrm{T}_{12}$ :Compost was applied @ $50 \mathrm{~kg} \mathrm{~N} \mathrm{ha}^{-1}$

$\left(50: 25 \mathrm{~N}: \mathrm{P}_{2} \mathrm{O}_{5} \mathrm{~kg} \mathrm{ha}^{-1}\right)+\mathrm{FYM} @ 3 \mathrm{t} \mathrm{ha}^{-1}\left(\mathrm{~T}_{14}: 39.7 \mathrm{q}\right.$ ha ${ }^{-1}$ and $13.2 \mathrm{t} \mathrm{ha}^{-1}$, respectively) followed by Cotton stalks + Redgram stalks + Glyricidia $s p$. with initial $\mathrm{C}: \mathrm{N}$ ratio of $30: 1$ compost @ $50 \mathrm{~kg} \mathrm{~N}$ equivalent $\left(\mathrm{T}_{12}\right.$ : $36.6 \mathrm{q} \mathrm{ha}^{-1} \& 12.9 \mathrm{t} \mathrm{ha}^{-1}$,respectively). The lowest was recorded with absolute control( $\mathrm{T}_{15}: 18.4 \mathrm{q} \mathrm{ha}^{-1} \& 9.5 \mathrm{t}$ $\mathrm{ha}^{-1}$, respectively). Higher grain and stover yield recorded with recommended FYM $\left(3 \mathrm{t} \mathrm{ha}^{-1}\right)$ and NP fertilizers $\left(50: 25 \mathrm{~kg} \mathrm{~N}, \mathrm{P}_{2} \mathrm{O}_{5} \mathrm{ha}^{-1}\right)$ application might be attributed to better availability of nutrients and root development with the integrated use of organic and inorganic manures. Increased grain yield due to appli- cation of recommended FYM $\left(3 \mathrm{tha}^{-1}\right)$ and NP fertilizers $\left(50: 25 \mathrm{~kg} \mathrm{~N}, \mathrm{P}_{2} \mathrm{O}_{5} \mathrm{ha}^{-1}\right)$ and Cotton stalks +Redgram stalks + Glyricidia sp. with $\mathrm{C}$ : $\mathrm{N}$ ratio of 30:1 compost@50 kg N equivalent could also be improvement in yield parameters like number of grains per plant (3204.6), 1000 seeds weight (34.4 g). These results are in agreement with the findings of Guled et al. (2003) who reported that reported that application of FYM at $5 \mathrm{t} \mathrm{ha}^{-1}+$ farmer's practice significantly increased the rabi sorghum grain yield, Kobayashi et al. (2008) also noticed the higher grain yield in the plot that received successive application of organic manure 
Table 4. Cost of cultivation, gross returns, net returns and B:C ratio of rabi sorghum as influenced by different crop residues and green biomass composts

\begin{tabular}{|c|c|c|c|c|}
\hline \multirow[t]{2}{*}{ Treatments } & $\begin{array}{l}\text { Cost of cultiva- } \\
\text { tion }\end{array}$ & $\begin{array}{c}\text { Gross re- } \\
\text { turns }\end{array}$ & Net returns & \multirow[t]{2}{*}{ B: C ratio } \\
\hline & & $\mathbf{h a}^{-1}$ & & \\
\hline $\mathrm{T}_{1}: \mathrm{C}_{1}$-Compost & 63781 & 100220 & 36439 & 1.57 \\
\hline $\mathrm{T}_{2}: \mathrm{C}_{2}$-Compost & 58718 & 103420 & 44702 & 1.76 \\
\hline $\mathrm{T}_{3}: \mathrm{C}_{3}$-Compost & 43211 & 107200 & 63989 & 2.48 \\
\hline $\mathrm{T}_{4}: \mathrm{C}_{4}$-Compost & 53767 & 104000 & 50233 & 1.93 \\
\hline $\mathrm{T}_{5}: \mathrm{C}_{5}$-Compost & 54641 & 104980 & 50339 & 1.92 \\
\hline $\mathrm{T}_{6}: \mathrm{C}_{6}$-Compost & 48016 & 104780 & 56764 & 2.18 \\
\hline $\mathrm{T}_{7}: \mathrm{C}_{7}$-Compost & 54829 & 106300 & 51471 & 1.94 \\
\hline $\mathrm{T}_{8}: \mathrm{C}_{8}$-Compost & 54033 & 109300 & 55267 & 2.02 \\
\hline $\mathrm{T}_{9}$ : $\mathrm{C}_{9}$-Compost & 48783 & 109680 & 60897 & 2.25 \\
\hline $\mathrm{T}_{10}: \mathrm{C}_{10}$-Compost & 45088 & 113600 & 68512 & 2.52 \\
\hline $\mathrm{T}_{11}: \mathrm{C}_{11}$-Compost & 43538 & 114580 & 71042 & 2.63 \\
\hline $\mathrm{T}_{12}: \mathrm{C}_{12}$-Compost & 41764 & 120960 & 79196 & 2.90 \\
\hline $\mathrm{T}_{13}$ : Recommended NP fertilizers $\left(50: 25 \mathrm{~kg} \mathrm{~N}, \mathrm{P}_{2} \mathrm{O}_{5} \mathrm{ha}^{-1}\right)$ & 40270 & 110720 & 70450 & 2.75 \\
\hline $\begin{array}{l}\mathrm{T}_{14}: \text { Recommended FYM }\left(3 \mathrm{tha}^{-1}\right) \text { and NP fertilizers }(50: 25 \\
\left.\mathrm{kg} \mathrm{N}, \mathrm{P}_{2} \mathrm{O}_{5} \mathrm{ha}^{-1}\right)\end{array}$ & 42082 & 129620 & 87538 & 3.08 \\
\hline $\mathrm{T}_{15}$ : Absolute control & 30070 & 65800 & 35730 & 2.19 \\
\hline S.Em \pm & 2469 & 4635 & 3205 & 0.09 \\
\hline C.D. $(P=0.05)$ & 7397 & 13895 & 9610 & 0.26 \\
\hline
\end{tabular}

$\mathrm{T}_{1}$ to $\mathrm{T}_{12}$ : Compost was applied @ $50 \mathrm{~kg} \mathrm{~N} \mathrm{ha}^{-1}$, Men and women labour @ Rs. 342 each, Bullock pair @ Rs. 500/day, Tractor

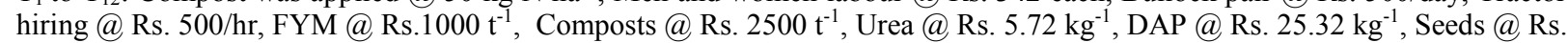
$52 \mathrm{~kg}^{-1}$, Sorghum grains @ Rs. $2600 \mathrm{q}^{-1}$, Stover @ Rs. $2000 \mathrm{t}^{-1}$ B:C: Benefit-cost ratio.

for 26 years (rice and barley straw or straw compost) than the non-organic manure plot, Similar results are also obtained by Ibrahim et al. (2011) in sorghum, Nandapure et al. (2011) in sorghum and wheat, Pholsen et al. (2004) in sorghum and Zafar et al. (2012) in maize.

Economic feasibility: Maximum gross returns was recorded with recommended FYM (3 $\left.\mathrm{t} \mathrm{ha}^{-1}\right)$ and NP fertilizers $\left(50: 25 \mathrm{~kg} \mathrm{~N}, \mathrm{P}_{2} \mathrm{O}_{5} \mathrm{ha}^{-1}\right)$ application $\left(\mathrm{T}_{14}\right.$ : Rs.1,29,620 ha-1) over other treatments and was on par with $\mathrm{C}_{12}$ compost @ $50 \mathrm{~kg} \mathrm{~N}$ equivalent ( $\mathrm{T}_{12}$ : Rs. $1,20,960 \mathrm{ha}^{-1}$ ). The lowest gross return (Rs. $65800 \mathrm{ha}^{-}$ $\left.{ }^{1}\right)$ was obtained with the absolute control $\left(T_{15}\right)$. While net return and $\mathrm{B}: \mathrm{C}$ ratio were also higher with recommended FYM $\left(3 \mathrm{t} \mathrm{ha}^{-1}\right)$ and NP fertilizers $(50: 25 \mathrm{~kg} \mathrm{~N}$, $\mathrm{P}_{2} \mathrm{O}_{5} \mathrm{ha}^{-1}$ ) application $\left(\mathrm{T}_{14}\right.$ : Rs. 87,538 $\mathrm{ha}^{-1}$ and 3.08, respectively) over other treatments and was on par with $\mathrm{C}_{12}$ compost@50 kg N equivalent ( $\mathrm{T}_{12}$ : Rs. $79,196 \mathrm{ha}^{-1}$ and 2.90, respectively). The least net return and $\mathrm{B}: \mathrm{C}$ ratio were obtained with absolute control and $\mathrm{C}_{1}$ compost@50 kg N equivalent $\left(\mathrm{T}_{15}\right.$ : Rs. 35,730 ha ${ }^{-1}$ and 1.57 , respectively). The higher gross returns in recommended FYM $\left(3 \mathrm{tha}^{-1}\right)$ and NP fertilizers $(50: 25$ $\mathrm{kg} \mathrm{N}, \mathrm{P}_{2} \mathrm{O}_{5}$ ha $^{-1}$ ) application could be attributed to the significantly more marketable grain and stover yield associated with better availability of nutrients. Similar results were recorded by Arjun and Anil (2009) who reported that application of FYM $5 \mathrm{t} \mathrm{ha}^{-1}+\mathrm{RDF}$ recorded highest benefit cost ratio of 1.51 as compared to application of FYM $5 \mathrm{t} \mathrm{ha}^{-1}$ alone (1.10) in maize. Highest net returns and $\mathrm{B}: \mathrm{C}$ ratio with recommended FYM (3 $\left.\mathrm{tha}^{-1}\right)$ and NP fertilizers (50:25 kg N, $\mathrm{P}_{2} \mathrm{O}_{5} \mathrm{ha}^{-}$ $\left.{ }^{1}\right)$ application due to reduced cost of cultivation as compared to different composts alone (Table 4). Lower yield caused reduced gross and returns in absolute control. These results are in line with Krishnamurthy (2003) who reported that maximum gross return, net return and benefit-cost ratio with the application of Glyricidia green biomass and poultry waste in 1:1 proportion compost at $125 \mathrm{~kg} \mathrm{~N}$ equivalent plus $125 \mathrm{~kg} \mathrm{~N}$ through fertilizer followed by Compost of Eupatorium green biomass + poultry waste $(1: 1 \mathrm{w} / \mathrm{w})$ compost at $125 \mathrm{~kg} \mathrm{~N}$ equivalent plus $125 \mathrm{~kg} \mathrm{~N}$ through fertilizer compared to control in rose red onion.

\section{Conclusion}

From this study it can be concluded that application of recommended FYM@3 tha ${ }^{-1} 15$ days before sowing along with $50 \mathrm{~kg}$ of nitrogen and $25 \mathrm{~kg}$ of phosphorus per hectare at the time of sowing recorded higher dry matter production, grain and stover yield and net returns and benefit: cost ratio. However, to realize the similar benefits of recommended package, in terms of dry matter production, grain yield, net returns and $\mathrm{B}: \mathrm{C}$ ratio, substitution of recommended dose of $\mathrm{N}$ can be made through the use of compost @ $3 \mathrm{t} \mathrm{ha}^{-1}$ prepared with Cotton stalks + Redgram stalks + Glyricidia green biomass with initial $\mathrm{C}: \mathrm{N}$ ratio of $30: 1$ of the mixed composting material. Sustainable yield and soil health index were higher in organic sorghum production system over fertilizers alone in addition to this the future challenge is supply of sufficient organic manures required to replenish nutrient requirement at large scale. 
It can be overcome by composting of cotton and redgram stalks in this region.

\section{REFERENCES}

Anonymous (2014). All-India Area, Production and Yield along with coverage under Irrigation, Agricultural Statistics at a Glance 2016. Retrieved on August 182016 http:// eands.dacnet.nic.in/PDF/Glance-2016.pdf.

Anonymous (2015). District wise area, production and productivity of major crops in Karnataka. Directorate of Economics \& Statistics, Bengaluru.

Arjun, S. and Anil, K. (2009). Effect of organic and integrated nutrient management on productivity and economics of rabi sorghum. Karnataka J. Agric. Sci., 22(1): 11-14.

Feisal,M.Ismaeil, Awad O. Abusuwar and Ahmed M.El Naim. (2012). Influence of chicken manure on growth and yield of forage sorghum (Sorghumbicolor L.).Inte.J.Agric.\& Forstry., 2(2):56-60.

Guled, M. B., Gundlur, S. S., Hiremath, K. A. and Surkod, V. S. (2003). Effect of organic and inorganic fertilizers on uptake of major nutrients by rabi sorghum. Karnataka J. Agric. Sci., 16(2): 304-306.

Ibrahim Elasdig Ibrahim, Ali Eltoum Hassan, Elasha,A. and SalihElagab. (2011). Effect of organic manure on yield and yield components of rainfed sorghum in Gedarif state. J. Sci. \& Tech., 12(4): 48-57.

Kobayashi, Y., Suzuki, S., Watanabe, N., Yoshizawa, T., Ueki, Y., Suzuki, T. and Kaneda, S. (2008). Effect of long-term organic matter application to double cropping paddy fields on rice (Oryza sativa L.) and barley (Hordeum vulgare L.) yields in Japan. Bull. of the TochigiPrefectural Agric. Expt. Station, 59: 11-23.

Krishnamurthy, D. (2003). Impact of sole and integrated use of organics on the productivity, quality and shelf-life of Bangalore rose red onion (Allium cepa L.). M.Sc Thesis, Univ. of Agric. Sci., Bangalore.

Nandapure, S. P., Sonune, B.A., Gabhane,V.V., Katkar, R.N. and Patil, R.T. (2011). Influence of long term fertilization on micronutrients availability, their uptake and productivity of sorghum - wheat sequence under semiarid condition on a vertisol. Crop Res., 42(1,2\&3):35-39

Panse, V. G. and Sukhatme, P. U. (1967). Statistical Methods for Agricultural Workers. ICAR, New Delhi.

Pholsen, S. and Sukari,A. (2004). Effect of organic amendment and chemical fertilizer on growth, yield and fodder quality of a forage sorghum(Sorghumbicolor L.). Paki. J. Bio. Sci.,7(4): 651-658.

Taylor, J R N. (2003). Overview: Importance of sorghum in Africa. Workshop on the Proteins of Sorghum and Millets: Enhancing Nutritional and Functional Properties for Africa held at Pretoria, South Africa, 2-4 April, 2003. Paper 01, pp.1-21.

Zafar, M., Abbasi,M.K., Arjumend,T. and Jabran,K. (2012). Impact of compost, inorganic phosphorus fertilizers and their combination on maize growth, yield, nutrient uptake and soil properties. J. Animal\& Plant. Sci., 22(4): 1036-1041. 